(c) American Dairy Science Association, 2004.

\title{
Feeding Glycerol to Transition Dairy Cows: Effects on Blood Metabolites and Lactation Performance
}

\author{
J. M. DeFrain, ${ }^{1}$ A. R. Hippen, ${ }^{1}$ K. F. Kalscheur, ${ }^{1}$ and P. W. Jardon ${ }^{2}$ \\ ${ }^{1}$ Dairy Science Department, \\ South Dakota State University, Brookings 57007 \\ ${ }^{2}$ West Central Soy, Ralston, IA 51459
}

\section{ABSTRACT}

Glycerol can alleviate the symptoms of ketosis when delivered as an oral drench. The addition of glycerol to the diet would eliminate the need for restraining cows for drenching yet deliver a glucogenic substrate, alleviate the fatty liver-ketosis complex, and improve lactational performance. For this study, 21 multiparous and 9 primiparous Holstein cows blocked by parity and expected calving date were used in a randomized block design to evaluate the effects of feeding glycerol from $14 \mathrm{~d}$ prepartum to $21 \mathrm{~d}$ in milk (DIM). Treatments $(\mathrm{kg} /$ d dry matter basis) were 0.86 of cornstarch (control), 0.43 cornstarch +0.43 glycerol (LG), or 0.86 glycerol (HG), topdressed and hand-mixed into the upper onethird of the daily ration. All cows were fed a common diet from 22 to 70 DIM. Prepartum dry matter intake (DMI) was greater for cows fed the control diet compared with LG or HG $(13.3,10.8$, and $11.3 \pm 0.50 \mathrm{~kg} /$ $\mathrm{d}$, respectively). Prepartum plasma glucose, insulin, $\beta$ hydroxybutyrate, nonesterified fatty acids, and ruminal profiles were not affected by treatments. Rumen fluid collected postpartum from cows fed LG and HG had greater total volatile fatty acids, greater molar proportions of propionate, and a decreased ratio of acetate to propionate. Furthermore, concentrations of butyrate tended to be greater in rumens of cows fed LG and HG. Postpartum concentrations of glucose in plasma were greatest for cows fed the control diet relative to $L G$ and HG (66.0 vs. 63.1 and $58.4 \mathrm{mg} / \mathrm{dL}$, respectively) and decreased sharply at 21 DIM, after treatments ended, for cows fed HG (diet $\times$ day interaction). Body weight and condition loss, plasma nonesterified fatty acids, and liver lipids during the first 21 DIM were similar among treatments. Postpartum DMI was not affected by treatments; however, a tendency was observed for a diet $\times$ day interaction for body weight, as cows fed LG gained more body weight from 21 to 70 DIM relative to cows

Received May 19, 2004

Accepted August 11, 2004.

Corresponding author: A. R. Hippen; e-mail: arnold_hippen@ sdstate.edu. fed HG. Yield of energy-corrected milk during the first 70 DIM tended to be greatest for cows fed the control diet. The LG and HG diets decreased urea nitrogen concentrations in milk relative to controls. Based upon prepartum DMI and concentrations of glucose and $\beta$ hydroxybutyrate in blood postpartum, feeding glycerol to dairy cows at the levels used in this experiment increased indicators used to gauge the degree of ketosis in dairy cattle.

(Key words: periparturient, glycerol, metabolite, lactation performance)

Abbreviation key: ECM = energy-corrected milk, HG = high glycerol, LG = low glycerol.

\section{INTRODUCTION}

Satisfying the nutritional requirements of the highproducing dairy cow is a challenge, particularly around the time of calving. Feed consumption during the week before calving declines $30 \%$ (Bertics et al., 1992). Typically, feed intake during the first 5 wk of lactation continues to be insufficient to match the increasing energy demands of lactation. During this time, the cow is in a negative energy balance; energy output in the form of milk exceeds energy input in the form of feed.

Because of our inability to overcome the intake depression observed around calving, producers are using oral drenches and pastes to deliver glucose precursors, such as calcium propionate and propylene glycol, to decrease ketosis and other fresh-cow metabolic disorders. Glycerol is an effective treatment against lactational ketosis in dairy cattle when administered in this manner, and enters the metabolic pathway to glucose in a different location than other glucogenic precursors (Leng, 1970). Johnson (1955) reported that the oral administration of $2 \mathrm{~kg}$ of glycerol was more effective in alleviating ketosis compared with propylene glycol. Fisher et al. (1971) concluded that the mode of action behind feeding glycerol could be attributed to an increase in feed intake and subsequent supply of more glucogenic substrate. Additional work by Fisher et al. (1973) found that cows fed glycerol at $374 \mathrm{~g} / \mathrm{d}$ lost less body weight and remained in a more positive energy 
balance than those fed glycerol or propylene glycol at $174 \mathrm{~g} / \mathrm{d}$. From these data, one could conclude that feeding glycerol as a topdress (vs. drenching) could potentially improve the health and lactational performance of peripartum dairy cows.

Recent interest in biodiesel as a renewable energy resource will create a surplus of glycerol stores (Crandall, 2004), a by-product of biodiesel production. As glycerol becomes more available, it will likely become less cost prohibitive as an aid in the treatment of ketosis. Australian workers (Schröder and Südekum, 1999) fed sheep 48, 78, 131, or $185 \mathrm{~g} / \mathrm{d}$ of glycerol (DM basis) in a low-starch, concentrate diet and found either no effect or positive effects on digestibility of organic matter, starch, and cell-wall components. However, feeding the same levels of glycerol in high-starch concentrate diets resulted in a decrease in cell-wall digestibility but no effect on the digestion of organic matter or starch. Furthermore, Schröder and Südekum (1999) found that feeding glycerol decreased the acetate:propionate ratio and stimulated water intake, both of which would benefit transition dairy cows.

Incorporation of glycerol into a complete diet has not been evaluated in peripartum dairy cows. The objectives of this experiment were to determine the effects of feeding glycerol 2 wk before and 3 wk after parturition on plasma metabolites, health, and lactation performance. We hypothesized that feeding glycerol would deliver a glucogenic substrate, alleviate the fatty liverketosis complex, and improve lactation performance.

\section{MATERIALS AND METHODS}

\section{Cows and Sampling}

Animal care and use was according to a protocol approved by the South Dakota State University Institutional Animal Care and Use Committee. The experiment was conducted from July through November 2002 at the South Dakota State University Dairy Teaching and Research Facility (Brookings, SD). Twenty-one multiparous and 9 primiparous Holstein cows, blocked by parity and expected calving date, were arranged into a randomized block design. The treatment groups consisted of 3 topdresses, which were hand-mixed into the upper one-third of the close-up (starting $21 \mathrm{~d}$ before expected calving) and fresh-cow (calving through 21 DIM) diets. The topdresses were (on DM basis) $0.86 \mathrm{~kg} /$ d cornstarch (control), $0.43 \mathrm{~kg} / \mathrm{d}$ cornstarch $+0.43 \mathrm{~kg} /$ d glycerol (LG), and $0.86 \mathrm{~kg} / \mathrm{d}$ glycerol (HG). All cows received a common diet from 22 to 70 DIM.

The ingredient and nutrient composition of the closeup, fresh, and high-group diets are shown in Tables 1
Table 1. Ingredient composition of close-up (offered $21 \mathrm{~d}$ before expected calving), fresh (offered 1 through $21 \mathrm{DIM}$ ), and high-group (offered 22 through 70 DIM) diets without topdressed ingredient(s). ${ }^{1}$

\begin{tabular}{|c|c|c|c|}
\hline \multirow[b]{2}{*}{ Ingredient } & \multicolumn{3}{|c|}{ Diet } \\
\hline & Close-up & Fresh & High-group \\
\hline & & $\%$ of diet & $M-$ \\
\hline Brome grass hay & 19.5 & & \\
\hline Alfalfa hay & 19.5 & 11.4 & 8.7 \\
\hline Alfalfa haylage & & 11.4 & 8.7 \\
\hline Corn silage & 37.3 & 24.9 & 27.3 \\
\hline Wet distillers grains & & 10.0 & 11.1 \\
\hline Whole cottonseed & 2.6 & 7.6 & 8.0 \\
\hline Dried distillers grains & 7.2 & $\ldots$ & \\
\hline Liquid whey ${ }^{2}$ & $\ldots$ & & 3.9 \\
\hline Corn grain, ground & $\ldots$ & 21.9 & 19.6 \\
\hline Soybean meal, $44 \%$ & 4.77 & 6.6 & 5.9 \\
\hline SoyChlor $16-7^{3}$ & 7.14 & & \\
\hline SoyPLUS ${ }^{3}$ & $\ldots$ & 2.7 & 2.4 \\
\hline Limestone & $\ldots$ & 1.14 & 1.01 \\
\hline Megalac $^{4}$ & $\ldots$ & & 1.20 \\
\hline Sodium bicarbonate & & 0.73 & 0.64 \\
\hline Calcium chloride & 0.73 & $\ldots$ & \\
\hline Dicalcium phosphate & & 0.33 & 0.31 \\
\hline Urea & 0.34 & 0.31 & 0.28 \\
\hline Vitamin $\mathrm{A}, \mathrm{D}$, and E premix & $0.69^{\mathrm{a}}$ & $0.25^{b}$ & $0.23^{b}$ \\
\hline Diamond V XP yeast ${ }^{5}$ & $\ldots$ & 0.23 & 0.19 \\
\hline Magnesium oxide & $\ldots$ & 0.21 & 0.19 \\
\hline Salt & & 0.21 & 0.19 \\
\hline Zinpro 4-plex ${ }^{6}$ & 0.08 & 0.06 & 0.05 \\
\hline Vitamin E premix $^{7}$ & 0.11 & 0.02 & 0.02 \\
\hline
\end{tabular}

aDry Cow Supreme, Land O' Lakes, Fort Dodge, IA. Assay, DM: $1.0 \% \mathrm{Ca}, 4.5 \% \mathrm{Mg}, 1.0 \% \mathrm{~K}, 1.0 \% \mathrm{~S}, 3150 \mathrm{ppm} \mathrm{Fe}, 1890 \mathrm{ppm} \mathrm{Cu}, 38$ ppm Co, $8280 \mathrm{ppm} \mathrm{Mn,} 8280 \mathrm{ppm} \mathrm{Zn,} \mathrm{454,000} \mathrm{IU/kg} \mathrm{vitamin} \mathrm{A,}$ 90,900 IU/kg vitamin D, 3636 IU/kg vitamin E.

'Dairy Micro Premix, Land O' Lakes, Fort Dodge, IA. Assay, DM: $10 \% \mathrm{Mg}, 9840 \mathrm{ppm} \mathrm{Fe}, 120 \mathrm{ppm} \mathrm{Cu}, 26,000$ ppm Mn, 26,000 ppm $\mathrm{Zn}, 400 \mathrm{ppm} \mathrm{I}, 140 \mathrm{ppm}$ Se, 909,000 IU/kg vitamin A, 182,000 IU/ $\mathrm{kg}$ vitamin D, $2424 \mathrm{IU} / \mathrm{kg}$ vitamin $\mathrm{E}$.

${ }^{1}$ Close-up and Fresh diets were topdressed (kg/d DM basis) with treatments of 0.86 corn starch (control), 0.43 corn starch +0.43 glycerol (LG), and 0.86 glycerol (HG).

${ }^{2}$ Contains $7.8 \% \mathrm{CP}, 70 \%$ lactose, $0.30 \% \mathrm{Ca}, 0.79 \% \mathrm{P}, 3.9 \% \mathrm{~K}$ on a DM basis.

${ }^{3}$ West Central Soy, Ralston, IA.

${ }^{4}$ Megalac calcium salts of palm oil (Church and Dwight Co., Inc., Princeton, NJ).

${ }^{5}$ Diamond V XP, Diamond V Mills, Inc., Cedar Rapids, IA.

${ }^{6} 4$-Plex, Zinpro Corp., Eden Prairie, MN.

${ }^{7}$ Contains 44,000 IU of vitamin E per $\mathrm{kg}$.

and 2 . The glycerol was produced by a soy-diesel facility (West Central Soy, Ralston, IA) and contained 80.2\% glycerol, $11.5 \%$ salt, $6.6 \%$ water, and $1.3 \%$ methanol. The amount of glycerol fed was determined from recent work by Goff and Horst (2001), who found that $0.83 \mathrm{~kg}$ of glycerol delivered by esophageal drench increased blood glucose by $16 \%$ within $30 \mathrm{~min}$. Our highest glycerol treatment was to be similar to that used by Goff and Horst (2001) to provide a reference point in identifying the efficacy of glycerol in elevating blood glucose when fed. Dietary treatments were formulated using 
Table 2. Nutrient composition of close-up (offered $21 \mathrm{~d}$ before expected calving), fresh (offered 1 through 21 DIM), and high-group (offered 22 through 70 DIM) diets.

\begin{tabular}{lccc}
\hline & \multicolumn{3}{c}{ Diet } \\
\cline { 2 - 4 } Nutrient & Close-up & Fresh & High-group \\
\hline DM, \% as fed & 51.1 & 52.4 & 47.0 \\
CP, \% of DM & 16.5 & 18.6 & 18.0 \\
RUP, $\%$ of CP & 35.6 & 35.5 & 35.7 \\
NE, Mcal/kg & 1.50 & 1.63 & 1.63 \\
ADF, \% of DM & 25.5 & 19.0 & 18.8 \\
NDF, \% of DM & 38.7 & 30.9 & 31.5 \\
NFC, \% of DM & 31.8 & 39.0 & 37.0 \\
Starch, \% of DM & 18.1 & 28.9 & 30.1 \\
Ether extract, \% of DM & 3.39 & 4.31 & 6.35 \\
Ash, \% of DM & 9.60 & 7.15 & 7.08 \\
Ca, \% of DM & 1.26 & 1.20 & 0.93 \\
P,\% of DM & 0.45 & 0.49 & 0.45 \\
Mg, \% of DM & 0.49 & 0.43 & 0.40 \\
K, \% of DM & 1.42 & 1.29 & 1.38 \\
Na, \% of DM & 0.15 & 0.32 & 0.50 \\
Cl, \% of DM & 1.40 & 0.39 & 0.47 \\
S, \% of DM & 0.25 & 0.28 & 0.21 \\
DCAD, ${ }^{3}$ meq/kg of DM & -122 & 185 & 310 \\
\hline
\end{tabular}

${ }^{1}$ Estimates from NRC (2001).

${ }^{2} \mathrm{NFC}=100-(\% \mathrm{NDF}+\% \mathrm{CP}+\%$ ether extract $+\%$ ash $)$.

${ }^{3} \mathrm{DCAD}=$ Dietary cation-anion difference as $[(\mathrm{Na}+\mathrm{K})-(\mathrm{Cl}+\mathrm{S})]$ in milliequivalents per kilogram of DM.

NRC (2001). Pretrial $\mathrm{NE}_{\mathrm{L}}$ estimates for glycerol and cornstarch were 1.92 and $2.16 \mathrm{Mcal} / \mathrm{kg}$ according to estimates calculated by the computer software package provided by NRC (2001). The analyzed nutrient composition of cornstarch and glycerol were substituted for the default values listed for corn grain, ground, dry displayed within the energy feeds category of the software program. Based on analyzed diet composition upon completion of the experiment, the revised $\mathrm{NE}_{\mathrm{L}}$ estimates of glycerol and cornstarch were 1.90 and 2.13 $\mathrm{Mcal} / \mathrm{kg}$, respectively, when formulated into the preand postfresh TMR. The cornstarch (Cargill, Inc., Minneapolis, MN) was considered a traditional glucogenic agent, as it is primarily fermented to propionate in the rumen. Furthermore, ruminal fermentation characteristics of steers fed glycerol indicate that glycerol ferments in a manner similar to a carbohydrate (vs. a fat) in the rumen when formulated into typical high-forage dairy diet (Schröder and Südekum, 1999).

Cows were housed on a wheat-straw bedded pack prepartum and in a free-stall barn during the postpartum phase of the experiment. Diets were mixed and fed daily at $0600 \mathrm{~h}$ for ad libitum consumption using the Calan Broadbent feeding system (American Calan, Inc., Northwood, NH). All diets were offered as a TMR. Weighbacks were measured, recorded, and discarded before feeding each day, and amounts fed were adjusted to ensure a $10 \%$ feed refusal. Samples of diets were collected weekly for analysis. Body weights and BCS
( 1 to 5 in 0.25 increments; Wildman et al., 1982) were recorded on 2 consecutive days, $4 \mathrm{~h}$ after feeding on $\mathrm{d}$ 21 before expected calving, at parturition, and on d 21 , 49 , and 70 DIM. The same individuals recorded BCS during the entire experiment. In addition, calf birth weights and calving difficulty scores were recorded $(1=$ no problem; $2=$ slight problem; $3=$ needed assistance; 4 = considerable force; 5 = caesarean). Cows were milked at 0600, 1400, and $2100 \mathrm{~h}$, and milk yield was recorded. Milk samples were collected on d 7, 14, and 21 of lactation from all 3 milkings each day. Samples were mixed 6 times by gentle inversion and composited in equal volumes for each cow on each sampling day. Composited samples were then analyzed for protein, fat, lactose, MUN, and SCC. Solids-not-fat was calculated.

Urine ketones were measured from a midstream urine sample daily during the first 7 DIM using Ketostix reagent strips sensitive to acetoacetic acid (Bayer Corporation Diagnostics Division, Elkart, IN). Cows with a urine Keto-stix value $\geq 80 \mathrm{mg} / \mathrm{dL}$ within the first 7 DIM were considered subclinically ketotic and were treated with $250 \mathrm{~mL}$ of dextrose (50\%, Bio-Ceutic Laboratories, St. Joseph, MO) after a blood sample was collected. Incidences of milk fever, metritis, displaced abomasum, mastitis, and foot aliments were recorded during the experiment.

Target day and actual day of blood sampling relative to calving were -14 and $-14.5(\mathrm{SD}=2.2),-7$ and -7.8 $(\mathrm{SD}=1.8),-2$ and $-2.6(\mathrm{SD}=1.0), 7$ and $7.4(\mathrm{SD}=1.0)$, 14 and $14.0(\mathrm{SD}=1.1)$, and 21 and $21.1(\mathrm{SD}=1.1)$, respectively. Approximately $4 \mathrm{~h}$ after feeding, blood was sampled from a coccygeal vessel into evacuated tubes (Becton Dickinson and Co., Franklin Lakes, NJ) containing K-EDTA. Samples were immediately placed on ice and transported to the laboratory. Samples were centrifuged $(500 \times \mathrm{g})$ and plasma was harvested and stored at $-20^{\circ} \mathrm{C}$ until further analysis. Ruminal fluid was collected $7 \mathrm{~d}$ before expected calving date and 14 $\mathrm{d}$ postpartum $4 \mathrm{~h}$ after feeding by applying vacuum pressure to an esophageal tube fitted with a suction strainer. To minimize saliva contamination, approximately $250 \mathrm{~mL}$ of rumen fluid was discarded before sample collection. Collected fluid was immediately analyzed for $\mathrm{pH}$ using a portable $\mathrm{pH}$ meter equipped with a combination electrode. Following $\mathrm{pH}$ determination, a $10-\mathrm{mL}$ sample was mixed with $2 \mathrm{~mL}$ of $25 \%$ (wt/vol) metaphosphoric acid and frozen at $-20^{\circ} \mathrm{C}$ until analyzed for concentrations of VFA and $\mathrm{NH}_{3} \mathrm{~N}$. Liver tissue was collected by trocar and aspiration between the 11th and 12th ribs (Smith et al., 1997) approximately $4 \mathrm{~h}$ after feeding on d 7, 14, and 21 of lactation. Samples were blotted to remove any residual blood, split into 2 equal aliquots, placed into cryovials, immediately submerged 
in liquid nitrogen, and transported to the laboratory where they were frozen at $-80^{\circ} \mathrm{C}$ until analysis.

\section{Laboratory Analysis}

Samples of diets were dried at $55^{\circ} \mathrm{C}$ in a forced-air oven and allowed to air-equilibrate before being ground to pass a 1-mm screen (Brinkmann ultracentrifuge mill, Brinkmann Instruments Co., Westbury, NY). Samples were composited by diet (prepartum and postpartum) and month and analyzed for CP (AOAC, 1997) using a LECO-428 combustion analyzer (LECO Corp., St. Joseph, MI), ether extract (AOAC, 1997), and lignin (AOAC, 1997). Neutral detergent fiber and ADF were measured using the ANKOM A200 (ANKOM Technology Corp., Fairport, NY) filter bag technique. Determination of ADF was according to AOAC (973.18 C, 1997), and NDF was according to Van Soest et al. (1991) with the addition of $4 \mathrm{~mL}$ of alpha amylase and $20 \mathrm{~g}$ of sodium sulfite. Minerals were quantified according to AOAC methods $(985.01,1997)$ using inductively coupled plasma spectrometer (Thermo Jarrell Ash, Franklin, MA).

Milk compositional analysis was conducted by Heart of America DHI Laboratory (Manhattan, KS) according to approved procedures of AOAC (1990). Milk true protein, fat, and lactose were determined using near infrared spectroscopy (Bentley 2000 Infrared Milk Analyzer, Bentley Instruments, Chaska, MN). Concentration of MUN was determined using chemical methodology based on a modified Berthelot reaction (ChemSpec 150 Analyzer, Bentley Instruments), and somatic cells were counted using a flow cytometer laser (Somacount 500, Bentley Instruments).

Coccygeal plasma samples were thawed and concentrations of glucose were determined using glucose oxidase (Sigma kit \#315, Sigma Diagnostics, St. Louis, MO) according to the procedures of Trinder (1969). Concentrations of BHBA in plasma were determined (Sigma kit 310-A, Sigma Diagnostics) following the methods of Williamson et al. (1962); plasma NEFA concentrations were determined using a colorimetric assay (NEFA-C kit, Wako Chemicals, Richmond, VA), following modifications by Johnson and Peters (1993). Insulin was quantified by solid-phase radioimmunoassay (Coat-A-Count, Diagnostic Products Corp., Los Angeles, CA) with an intraassay CV of $2.3 \%$. An attempt was made to quantify concentrations of glycerol in plasma using HPLC (model 2410, Waters Corp., Milford, MA) and a refractive index detector; however, concentrations were undetectable. Using a mobile phase $(0.6 \mathrm{~mL} /$ min) of $0.01 \mathrm{~N} \mathrm{H}_{2} \mathrm{SO}_{4}$, samples (50- $\mu \mathrm{L}$ injection volume) were injected onto an organic acid column $(300 \times 7.8$ mm, HPX87H, Bio-Rad Laboratories, Hercules, CA) with a constant temperature and pressure of $65^{\circ} \mathrm{C}$ and 4.62 $\mathrm{MPa}$, respectively. Concentrations of glycerol were undetectable.

Samples of liver tissue were thawed and analyzed for total lipid (Mills, et al., 1986) and glycogen (Derling et al., 1987). For determination of $\mathrm{NH}_{3} \mathrm{~N}$ and VFA, ruminal samples were thawed and centrifuged at 30,000 $\times g$ for 20 min at $4^{\circ} \mathrm{C}$. Ammonia concentrations were determined following the general protocol of Broderick and Kang (1980). Concentrations of VFA were measured by gas capillary chromatography (model 6890, Hewlett-Packard) using a $0.25 \mathrm{~mm}$ i.d. $\times 15 \mathrm{~m}$ column (Nukol, 17926 to 01C, Supelco, Inc., Bellefonte, PA) and a flame ionization detector. The split ratio in the injector port $\left(250^{\circ} \mathrm{C}\right)$ was $100: 1$ with the column described and a flow of $1.3 \mathrm{~mL} / \mathrm{min}$ of He. Column and detector temperature were maintained at 130 and $225^{\circ} \mathrm{C}$, respectively.

\section{Statistical Analyses}

Data from one multiparous cow fed HG was omitted from the final data set because of an unsuccessful recovery from health complications unrelated to treatment. Postpartum data from 2 primiparous cows fed HG were omitted because of complications associated with abomasal displacements. Among the cows remaining, 4 were treated for metritis, 2 for ketosis, 6 for mastitis, and 1 for a foot aliment. Effects of treatments on incidences of health disorders were not analyzed for statistical differences because of insufficient replication; however, all cows experiencing disorders were included in the data set, excluding those mentioned.

Milk yield and DMI data were reduced to weekly means for statistical analysis. Milk production data collected on the day of calving was not included in the data set because of the inherent difficulties associated with data collected on the day of calving. With the exception of rumen fluid variables, data were analyzed as repeated measures using PROC MIXED (Littell et al., 1996) of SAS software, version 8.1 (1999). For each variable, cow was subjected to 4 covariance structures: autoregressive order one, toeplitz, variance component, and compound symmetry. The structure yielding the largest Akaike's information criteria was used. For variables measured over time, the model included treatment, parity, time (week or day depending on the variable), and 2- and 3-way interactions as fixed effects. For the rumen fluid data, the model included treatment, parity, and treatment $\times$ parity interaction. The random effect was diet and parity nested within cow. The method of Kenward-Rogers was used for calculation of denominator degrees of freedom for $F$-tests. Covariates of initial BW and BCS and days on treatment were 
Table 3. Previous 305-d mature-equivalent milk, days on treatment, BW, BCS, calf birth weights, and calving difficulty of cows fed control (C), LG, and HG diets. ${ }^{1}$

\begin{tabular}{|c|c|c|c|c|c|c|}
\hline \multirow[b]{2}{*}{ Item } & \multicolumn{3}{|c|}{ Diet } & \multirow[b]{2}{*}{ SEM } & \multicolumn{2}{|c|}{ Contrast $^{2}$} \\
\hline & $\mathrm{C}$ & LG & HG & & 1 & 2 \\
\hline & & & & & 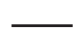 & - \\
\hline No. prepartum & 10 & 10 & 9 & $\ldots$ & $\ldots$ & $\ldots$ \\
\hline No. postpartum & 10 & 10 & 7 & & $\ldots$ & \\
\hline Previous $305 \mathrm{ME},{ }^{3} \mathrm{~kg}$ & 11,000 & 11,274 & 10,866 & 465 & 0.90 & 0.54 \\
\hline Days on treatment & 37.1 & 35.7 & 34.1 & 1.55 & 0.26 & 0.42 \\
\hline $\mathrm{BW},{ }^{4} \mathrm{~kg}$ & 723 & 737 & 751 & 20.3 & 0.40 & 0.61 \\
\hline $\mathrm{BCS}^{4,5}$ & 3.76 & 3.74 & 3.81 & 0.09 & 0.87 & 0.57 \\
\hline Calf BW, kg & 39.6 & 43.0 & 44.0 & 1.52 & 0.04 & 0.65 \\
\hline Calving difficulty ${ }^{6}$ & 1.5 & 2.2 & 2.1 & 0.38 & 0.21 & 0.85 \\
\hline
\end{tabular}

${ }^{1} \mathrm{LG}=$ Glycerol at $430 \mathrm{~g} / \mathrm{d}, \mathrm{HG}=$ glycerol at $860 \mathrm{~g} / \mathrm{d}$.

${ }^{2}$ Contrasts: $1=\mathrm{C}$ vs. LG and HG, 2 = LG vs. HG.

${ }^{3}$ Multiparous cows only.

${ }^{4}$ Collected $21 \mathrm{~d}$ before expected calving.

${ }^{5}$ Wildman et al., 1982.

${ }^{6}$ Five-point scale: 1 = no assistance, 2 = slight problem, 3 = needed assistance, 4 = considerable force, and $5=$ caesarean.

included for all data sets. Covariates and any interactions were dropped from the model one at time, starting with the least significant, and continuing until all remaining interactions and covariates were significant. Prepartum and postpartum data were analyzed separately. Preplanned contrasts were glycerol vs. no glycerol (control vs. LG and HG) and LG vs. HG. The purpose of comparing control vs. both LG and HG was to test the effect of glycerol supplementation, regardless of amount. The LG vs. HG contrast was used to determine the effect of glycerol inclusion level. Least square means and standard error of means are reported. Statistical significance was declared at $P<0.05$, with trends noted at $P=0.05$ to $P<0.15$.

\section{RESULTS}

Cows used in the study are characterized in Table 3. Treatments were fed for an average of $36 \mathrm{~d}$ (SD $=4.5$ d). Body weights and BCS $21 \mathrm{~d}$ before expected calving date were similar among treatments $(P>0.15)$. Calf birth weights were greater $(P=0.04)$ for cows fed LG and $\mathrm{HG}$ diets relative to those fed the control (43.0 and 44.0 vs. $39.6 \mathrm{~kg}$, respectively); however, birthing difficulties were not affected by treatments. Placental weights were not measured.

Supplementing glycerol decreased $(P<0.01)$ prepartum DMI (Table 4). Cows fed LG and HG diets consumed approximately $17 \%$ less DM relative to cows fed the control diet (10.8 and 11.3 vs. $13.3 \mathrm{~kg} / \mathrm{d}$, respectively); however, prepartum DMI was similar for cows fed LG and HG. Postpartum DMI and BCS were not affected by diet. A tendency was observed for a diet $\times$ day interaction (Figure $1 \mathrm{~B}, P=0.11$ ) for $\mathrm{BW}$, as cows fed LG gained more BW after 21 DIM relative to cows fed HG. Body weight increased by 17, 42, and $4 \mathrm{~kg}$ for cows fed control, LG, and HG, respectively, from 21 to 70 DIM (Figure 1B).

Milk yield and milk composition data are presented in Table 5. Feeding glycerol did not affect milk yield; however, feeding LG and HG tended $(P=0.09)$ to decrease yields of energy-corrected milk (ECM; Orth, 1992) relative to cows fed the control (35.2 and $35.0 \mathrm{vs.}$ $38.7 \mathrm{~kg} / \mathrm{d}$, respectively). The decrease in ECM yield was largely driven by a tendency $(P=0.13)$ for a decrease in milk fat yield by cows fed LG and HG compared with those fed the control (1.32 and 1.36 vs. $1.52 \mathrm{~kg} / \mathrm{d}$, respectively). Feeding LG and HG tended $(P=0.08)$ to decrease MUN relative to cows fed the control diet (13.72 and 14.05 vs. 15.25 , respectively).

Effects of treatments on concentrations of plasma metabolites are shown in Table 6. Treatments did not affect prepartum concentrations of glucose, insulin, NEFA, and BHBA; however, postpartum concentrations of glucose in plasma tended $(P=0.12)$ to be greatest for cows fed the control relative to LG and HG (65.8 vs. 63.0 and $60.1 \mathrm{mg} / \mathrm{dL}$, respectively). During the postpartum period, significant interactions of diet and day were observed for concentrations of glucose, insulin, NEFA, and BHBA. The postpartum diet $\times$ day interaction was observed for postpartum plasma glucose concentrations ( $P=0.01$, Figure 2A). Plasma glucose was decreased in cows fed LG at 7 DIM; however, concentrations of glucose in cows fed HG decreased sharply from d 14 to d 21 postpartum. Similar to concentrations of glucose in plasma, from $\mathrm{d} 7$ to 21 postpartum, concentrations of insulin in cows fed LG steadily increased; whereas plasma insulin concentrations in cows fed the 
Table 4. Dry matter intake, body weight, and body condition score of cows and heifers fed control (C), LG, and HG diets. ${ }^{1}$

\begin{tabular}{|c|c|c|c|c|c|c|}
\hline \multirow[b]{2}{*}{ Item } & \multicolumn{3}{|c|}{ Diet } & \multirow[b]{2}{*}{ SEM } & \multicolumn{2}{|c|}{ Contrast $^{2}$} \\
\hline & $\mathrm{C}$ & LG & HG & & 1 & 2 \\
\hline & & & & & $\longrightarrow$ & 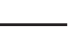 \\
\hline Prepartum DMI, kg/d & 13.3 & 10.8 & 11.3 & 0.50 & 0.001 & 0.43 \\
\hline Postpartum DMI, kg/d & 17.9 & 17.5 & 15.8 & 1.45 & 0.45 & 0.40 \\
\hline $\mathrm{BW},{ }^{3} \mathrm{~kg}$ & 658 & 667 & 664 & 17.8 & 0.71 & 0.91 \\
\hline $\mathrm{BCS}$ & 3.28 & 3.32 & 3.30 & 0.06 & 0.66 & 0.88 \\
\hline
\end{tabular}

${ }^{1} \mathrm{LG}=$ Glycerol at $430 \mathrm{~g} / \mathrm{d}, \mathrm{HG}=$ glycerol at $860 \mathrm{~g} / \mathrm{d}$.

${ }^{2}$ Contrasts: $1=\mathrm{C}$ vs. LG and HG, $2=$ LG vs. HG.

${ }^{3}$ Diet $\times$ day interaction $(P=0.11)$.

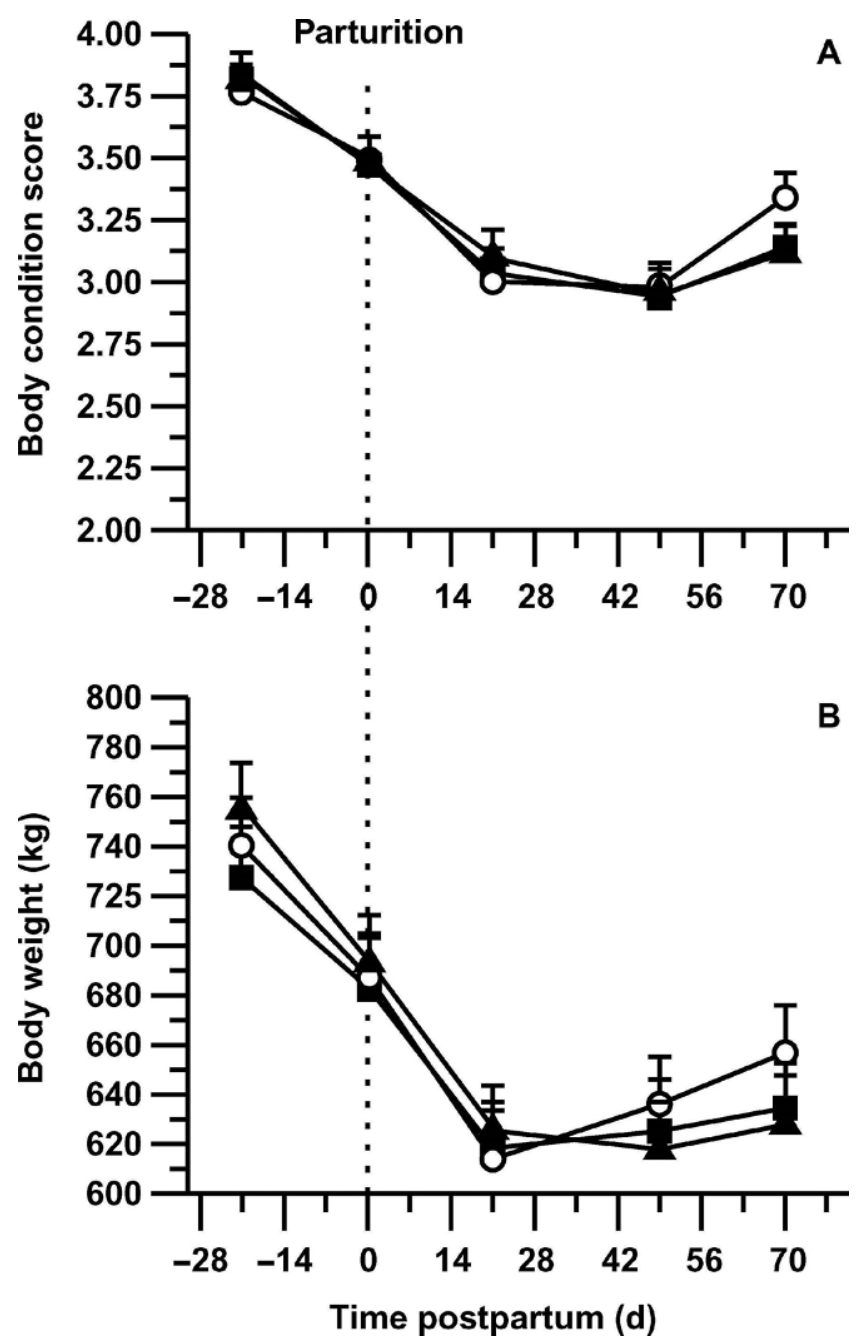

Figure 1. Body weight (A) and body condition score (B) (pooled $\mathrm{SEM}=19.2$ and 0.095 , respectively) of cows fed a control diet (C, squares), $430 \mathrm{~g} / \mathrm{d}$ glycerol (LG, open circles), and $860 \mathrm{~g} / \mathrm{d}$ glycerol (HG, triangles). control and HG diets remained constant (diet $\times$ day interaction, $P=0.02$, Figure 2B). Concentrations of BHBA in plasma decreased in cows fed LG and were unchanged in cows fed the control, whereas BHBA steadily increased between 7 and 21 DIM for cows fed HG (diet $\times$ day interaction, $P=0.12$, Figure $3 \mathrm{~A}$ ). Nonesterified fatty acids were greater in cows fed the control and LG at 7 DIM relative to cows fed HG; however, concentrations became similar among treatments at 14 and 21 DIM (diet $\times$ day interaction, $P=0.03$, Figure $3 \mathrm{~B})$. No differences in liver lipid and glycogen composition were observed (Figure 4).

Rumen fluid characteristics are presented in Table 7. With the exception of $\mathrm{NH}_{3} \mathrm{~N}$, dietary treatments did not affect prepartum ruminal $\mathrm{pH}$ or molar proportions of VFA. It is important to note that data characterizing ruminal fluid represent samples collected via esophageal tube and might have been contaminated with saliva. Feeding HG tended $(P=0.12)$ to decrease prepartum concentrations of $\mathrm{NH}_{3} \mathrm{~N}$ in rumen fluid (2.42 vs. $3.88 \mathrm{mg} / \mathrm{dL}$, respectively). Postpartum ruminal $\mathrm{pH}$ tended $(P=0.12)$ to be greater for cows fed LG than for those fed HG (6.89 vs. 6.61, respectively). Although molar proportions of butyrate were not affected by diets, cows fed LG and HG tended $(P=0.06)$ to have greater concentrations of ruminal butyrate relative to those fed the control diet at 7 DIM $(9.94,8.62$, and $7.03 \pm 0.99$, respectively; data not shown). Feeding LG and HG also tended $(P=0.06)$ to increase postpartum total VFA concentrations relative to cows fed the control (70.2 and 61.4 vs. 56.2, respectively). The ratio of acetate to propionate in rumen fluid collected postpartum was greater $(P<0.01)$ in cows fed the control diet relative to cows fed LG and HG (2.92 vs. 2.07 and 2.40, respectively). Effects of diets on the ratio of acetate to propionate in rumen fluid was primarily a result of changes in proportions of propionate, as feeding LG and $\mathrm{HG}$ increased $(P<0.01)$ proportions of propionate by nearly $20 \%$ relative to controls (27.1 and 24.7 vs. 21.7 , respectively). 
Table 5. Milk yield and composition of cows and heifers fed control (C), LG, and HG diets. ${ }^{1}$

\begin{tabular}{|c|c|c|c|c|c|c|}
\hline \multirow[b]{2}{*}{ Item } & \multicolumn{3}{|c|}{ Diet } & \multirow[b]{2}{*}{ SEM } & \multicolumn{2}{|c|}{ Contrast $^{2}$} \\
\hline & $\mathrm{C}$ & LG & HG & & 1 & 2 \\
\hline & & & & & 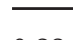 & - \\
\hline Milk yield, kg/d & 37.2 & 35.7 & 34.0 & 1.66 & 0.23 & 0.46 \\
\hline $\mathrm{ECM}^{3}$ yield, $\mathrm{kg} / \mathrm{d}$ & 38.7 & 35.2 & 35.0 & 1.82 & 0.09 & 0.93 \\
\hline Fat, \% & 4.26 & 4.02 & 4.26 & 0.22 & 0.65 & 0.43 \\
\hline True protein, \% & 2.94 & 3.02 & 2.97 & 0.08 & 0.60 & 0.61 \\
\hline Solids-not-fat, $\%$ & 8.67 & 8.79 & 8.63 & 0.12 & 0.79 & 0.33 \\
\hline Lactose, \% & 4.81 & 4.80 & 4.72 & 0.06 & 0.55 & 0.39 \\
\hline Fat, kg/d & 1.52 & 1.32 & 1.36 & 0.10 & 0.13 & 0.81 \\
\hline True protein, kg/d & 1.03 & 0.99 & 0.95 & 0.04 & 0.17 & 0.36 \\
\hline Solids-not-fat, kg/d & 3.01 & 2.90 & 2.78 & 0.14 & 0.27 & 0.49 \\
\hline Lactose, $\mathrm{kg} / \mathrm{d}$ & 1.66 & 1.60 & 1.53 & 0.09 & 0.32 & 0.54 \\
\hline $\mathrm{SCC} \times 10^{3} / \mathrm{mL}$ & 407 & 316 & 129 & 257 & 0.53 & 0.60 \\
\hline Milk urea $\mathrm{N}, \mathrm{mg} / \mathrm{dL}$ & 15.3 & 13.7 & 14.1 & 0.66 & 0.08 & 0.72 \\
\hline
\end{tabular}

\section{DISCUSSION}

Demand for renewable energy resources will increase the availability of glycerol (Crandall, 2004), making it less costly as a preventative for ketosis in dairy cattle. Furthermore, incorporating glycerol into a TMR would decrease the likelihood of cows developing toxicity (Goff and Horst, 2001) as compared with other glucogenic agents such as propylene glycol. This report documents the most recent evaluation of glycerol as a glucogenic feed additive for dairy cows since the early 1970s (Fisher et al., 1971; 1973).

Decreased prepartum DMI in this study is contradictory to previous studies (Fisher et al., 1971; 1973). Relative to cows fed propylene glycol, Fisher et al. (1971) found glycerol to act as an appetite stimulant when fed at $472 \mathrm{~g} / \mathrm{d}$ within the concentrate mix of a componentbased diet. In a more extensive experiment using a larger number of cows and an 8-wk treatment period, Fisher et al. (1973) found that feeding glycerol at 174 or $347 \mathrm{~g} / \mathrm{d}$ was ineffective at improving feed intake, milk yield, and energy balance relative to cows fed an unsupplemented control concentrate or propylene glycol. Differences in results between our study and the earlier work of Fisher et al. (1971; 1973) might be due to differences between component-fed diets vs. TMR. Because feeding LG and HG decreased prepartum but not postpartum DMI, one could speculate that the glucogenic potential of glycerol may be most efficaciously

Table 6. Concentrations of plasma BHBA, glucose, NEFA, and insulin and liver lipid and glycogen content of cows fed control (C), LG, and HG diets. ${ }^{1}$

\begin{tabular}{|c|c|c|c|c|c|c|}
\hline \multirow[b]{2}{*}{ Item } & \multicolumn{3}{|c|}{ Diet } & \multirow[b]{2}{*}{ SEM } & \multicolumn{2}{|c|}{ Contrast $^{2}$} \\
\hline & $\mathrm{C}$ & LG & $\mathrm{HG}$ & & 1 & 2 \\
\hline & & & & & $\longrightarrow$ & 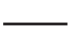 \\
\hline \multicolumn{7}{|l|}{ Prepartum } \\
\hline Glucose, mg/dL & 71.4 & 73.3 & 70.5 & 1.8 & 0.79 & 0.25 \\
\hline Insulin, $\mathrm{pg} / \mathrm{mL}$ & 135.9 & 110.4 & 117.2 & 14.9 & 0.25 & 0.74 \\
\hline NEFA, $\mu \mathrm{Eq} / \mathrm{L}$ & 172 & 174 & 200 & 37.5 & 0.74 & 0.6 \\
\hline $\mathrm{BHBA}, \mathrm{mg} / \mathrm{dL}$ & 1.30 & 2.17 & 1.89 & 0.84 & 0.48 & 0.81 \\
\hline \multicolumn{7}{|l|}{ Postpartum } \\
\hline Glucose ${ }^{3} \mathrm{mg} / \mathrm{dL}$ & 65.8 & 63.0 & 60.1 & 2.3 & 0.12 & 0.37 \\
\hline Insulin, ${ }^{3} \mathrm{pg} / \mathrm{mL}$ & 69.9 & 73.2 & 73.7 & 5.2 & 0.56 & 0.95 \\
\hline NEFA, ${ }^{3} \mu \mathrm{Eq} / \mathrm{L}$ & 624 & 639 & 495 & 94.4 & 0.60 & 0.28 \\
\hline $\mathrm{BHBA}^{3}{ }^{3} \mathrm{mg} / \mathrm{dL}$ & 4.31 & 6.18 & 5.43 & 1.50 & 0.40 & 0.72 \\
\hline Liver lipid, \% wet weight & 6.15 & 9.80 & 9.81 & 4.99 & 0.64 & 0.99 \\
\hline Liver glycogen, $\%$ wet weight & 1.79 & 1.82 & 1.85 & 0.07 & 0.61 & 0.66 \\
\hline
\end{tabular}

${ }^{1} \mathrm{LG}=$ Glycerol at $430 \mathrm{~g} / \mathrm{d}, \mathrm{HG}=$ glycerol at $860 \mathrm{~g} / \mathrm{d}$.

${ }^{2}$ Contrasts: $1=\mathrm{C}$ vs. LG and HG, $2=\mathrm{LG}$ vs. HG.

${ }^{3}$ Diet $\times$ day interaction $(P<0.05)$. 

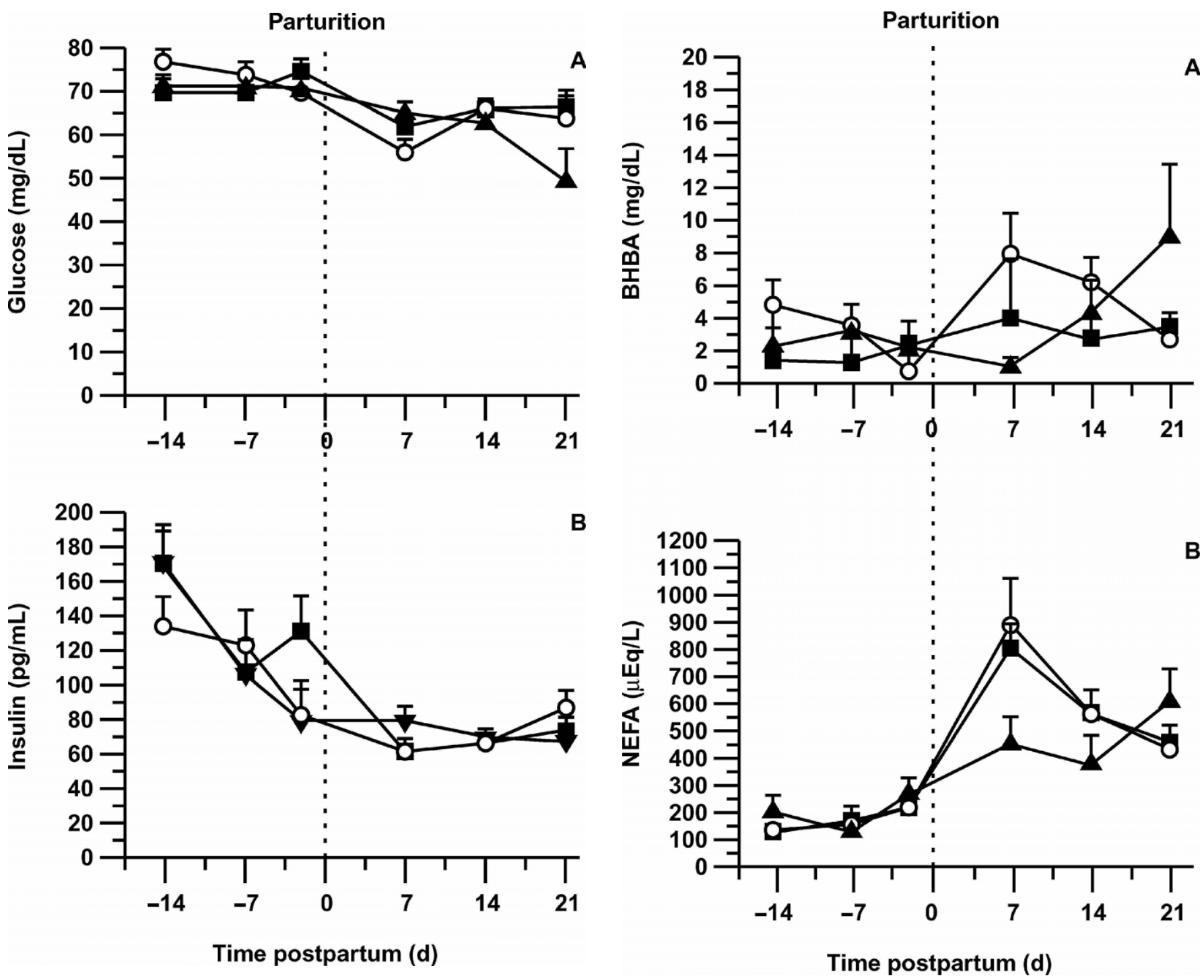

Figure 2. Plasma glucose (A) and insulin concentrations (B) (pooled SEM = 4.16 and 9.03, respectively) of cows fed a control diet (C, squares), $430 \mathrm{~g} / \mathrm{d}$ glycerol (LG, open circles), and $860 \mathrm{~g} / \mathrm{d}$ glycerol (HG, triangles).

used only during lactation; however, this hypothesis has yet to be tested.

Dietary treatments did not affect average BW or BCS; however, a tendency (diet $\times$ day interaction) was noted for BW (Figure 1B). All treatments maintained (control and HG) or increased (LG) BW from 21 to 70 DIM. Cows fed LG tended to increase BW at a greater rate relative to those fed the control diet or the greater quantity of glycerol. This response is similar to those of Fisher et al. (1973), who fed an amount of glycerol (374 g/d) similar to that used in cows fed LG in the current experiment $(430 \mathrm{~g} / \mathrm{d})$. Fisher et al. (1973) found that cows fed glycerol at $347 \mathrm{~g} / \mathrm{d}$ during the first $8 \mathrm{wk}$ of

Figure 3. Plasma BHBA (A) and NEFA (B) concentrations (pooled SEM = 111 and 1.95, respectively) of cows fed a control diet $(C$, squares), $430 \mathrm{~g} / \mathrm{d}$ glycerol (LG, open circles), and $860 \mathrm{~g} / \mathrm{d}$ glycerol (HG, triangles).

lactation lost less body weight $(P<0.10)$ than cows fed glycerol at $174 \mathrm{~g} / \mathrm{d}$, propylene glycol at $174 \mathrm{~g} / \mathrm{d}$, or a corn-based control concentrate.

With the exception of milk fat yield and MUN, there was no effect of treatments on milk yield or milk composition (Table 5). Other glycerol feeding studies (Fisher et al., 1971, 1973; Khalili et al., 1997) have found no effect of glycerol on milk yield. The tendency for greater ECM yields from cows fed the control diet was largely driven by yields of milk fat that tended to be lower for cows fed LG and HG. Relative to cows fed propylene glycol, Fisher et al. (1971) observed no effect of milk 

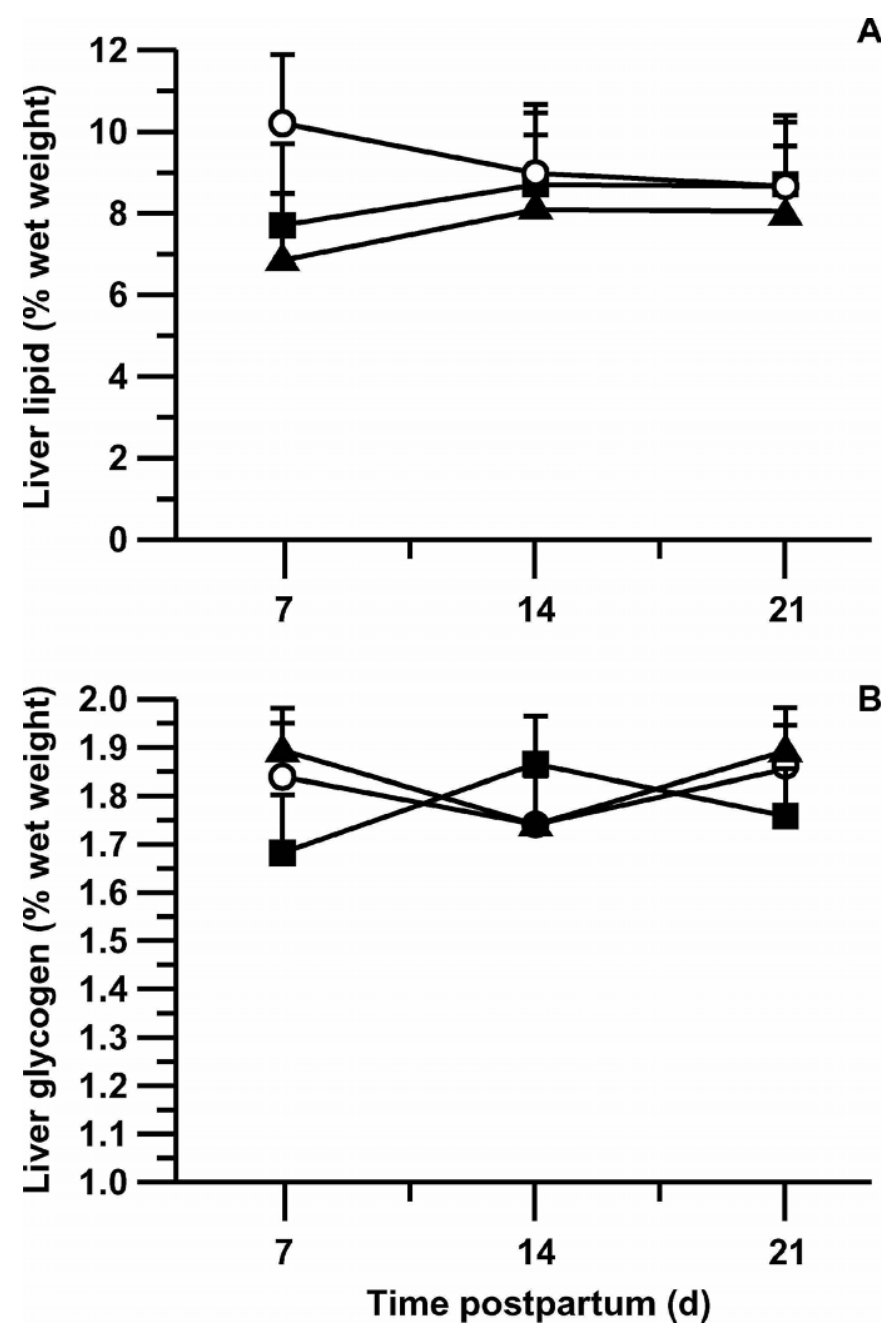

Figure 4. Liver lipid (A) and glycogen (B) composition (pooled $\mathrm{SEM}=1.74$ and 0.09 , respectively) of cows fed a control diet $(\mathrm{C}$, squares), $430 \mathrm{~g} / \mathrm{d}$ glycerol (LG, open circles), and $860 \mathrm{~g} / \mathrm{d}$ glycerol (HG, triangles).

fat yield of cows fed $472 \mathrm{~g} / \mathrm{d}$ glycerol. Effects of treatments on yields of milk fat agree with the decrease in the ruminal acetate to propionate ratio observed in in vivo glycerol fermentation studies (Table 7; Rémond et al., 1993; Schröder and Südekum, 1999). Although MUN tended (Table 5) to decrease in cows fed glycerol, a corresponding decrease in ruminal $\mathrm{NH}_{3} \mathrm{~N}$ was not observed in glycerol-supplemented cows.

Feeding glycerol tended to decrease milk fat and MUN and decreased the ruminal acetate to propionate ratio. It is likely that glycerol underwent ruminal fermentation to propionate similar to a fermentable carbohydrate source. Schröder and Südekum (1999) suggested that glycerol of different purities could replace rapidly fermentable starches in diets for ruminants at
A up to $10 \%$ of the diet DM. Our results corroborate the in vivo glycerol fermentation results of Schröder and Südekum (1999) and Khalili et al. (1997), where the ruminal acetate to propionate ratio decreased when feeding glycerol at 1.1 and $0.216 \mathrm{~kg} / \mathrm{d}$, respectively. With the exception of a tendency for a decrease in $\mathrm{NH}_{3}$ $\mathrm{N}$ for cows fed glycerol, treatments did not affect prepartum ruminal measurements (Table 7); however, differences were notable postpartum. Perhaps differences between ruminal effects of glycerol in prepartum and postpartum diets were attributable to dietary forage composition (76 and 48\% decreases, respectively).

Schröder and Südekum (1999) fed glycerol at 46, 98, 116 , and $155 \mathrm{~g} / \mathrm{d}$ (DM basis) in a low-starch concentrate diet and found either no effect or positive effects on digestibilities of organic matter, starch, and cell wall components in sheep. Feeding similar levels of glycerol in high-starch concentrate diets, however, resulted in a reduction in cell-wall digestibility. Therefore, one possibility for the observed differences between dietary treatments could be the effects of glycerol on ruminal fermentation and diet digestibility when cows transitioned from the low-concentrate prepartum diet to the high-concentrate postpartum diet. Although not measured in this study, perhaps the negative effects of glycerol on cell wall digestibility were responsible for the unfavorable postpartum lactation performance of cows fed HG.

Relative to its traditional counterparts, most notably propionate and propylene glycol, glycerol is at a metabolic advantage because it enters the gluconeogenic pathway at the triose phosphate level (Leng, 1970), metabolically closer to glucose. Therefore, glycerol does not depend on the rate-limiting enzymes pyruvate carboxylase or phosphoenolpyruvate carboxykinase for its conversion to glucose via glycerol kinase. Glycerol kinase converts glycerol $\left(K_{\mathrm{m}}=3\right.$ to $10 \mu \mathrm{M}$ [Lin, 1977]) and ATP to glycerol-3-phosphate and ADP, an intermediate step where glycerol is directed toward either gluconeogenesis or glycolysis. These data are the first reported on the effects of feeding glycerol on plasma metabolites of transition dairy cows (Table 6). No differences were detected for prepartum concentrations of glucose, insulin, NEFA, or BHBA; however, feeding glycerol tended to decrease postpartum concentrations of glucose in plasma. In contrast, Goff and Horst (2001) drenched $0.83,1.66$, and $2.49 \mathrm{~kg}$ of glycerol via esophageal pump and observed that concentrations of blood glucose increased by 16,20 , and $25 \%$ for cows treated with 0.83 , 1.66 , and $2.49 \mathrm{~kg}$ of glycerol, respectively, $30 \mathrm{~min}$ after dosing. Linke et al. (2004) compared delivery methods of glycerol (feeding vs. drenching $800 \mathrm{~g}$ ) and found drenching to be more efficacious at increasing plasma glucose and insulin concentrations. The amount of glyc- 
Table 7. Ruminal $\mathrm{pH}, \mathrm{NH}_{3} \mathrm{~N}$, and volatile fatty acid proportions of cows fed control (C), LG, and HG diets. ${ }^{1}$

\begin{tabular}{|c|c|c|c|c|c|c|}
\hline \multirow[b]{2}{*}{ Item } & \multicolumn{3}{|c|}{ Diet } & \multirow[b]{2}{*}{ SEM } & \multicolumn{2}{|c|}{ Contrast $^{2}$} \\
\hline & $\mathrm{C}$ & LG & HG & & 1 & 2 \\
\hline & & & & & $\longrightarrow$ & 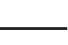 \\
\hline \multicolumn{7}{|l|}{ Prepartum } \\
\hline $\mathrm{pH}$ & 7.30 & 7.06 & 7.12 & 0.17 & 0.41 & 0.84 \\
\hline $\mathrm{NH}_{3} \mathrm{~N}, \mathrm{mg} / \mathrm{dL}$ & 3.73 & 3.88 & 2.42 & 0.67 & 0.48 & 0.12 \\
\hline Total VFA, mM & 54.5 & 56.3 & 63.9 & 7.9 & 0.62 & 0.55 \\
\hline \multicolumn{7}{|c|}{ VFA, molar proportions } \\
\hline Acetate & 61.8 & 57.9 & 59.6 & 2.4 & 0.29 & 0.63 \\
\hline Propionate & 22.9 & 25.2 & 24.2 & 1.7 & 0.36 & 0.67 \\
\hline Isobutyrate & 0.72 & 0.77 & 0.77 & 0.14 & 0.77 & 0.98 \\
\hline Butyrate & 12.4 & 14.0 & 12.9 & 1.12 & 0.42 & 0.49 \\
\hline Isovalerate & 1.12 & 0.99 & 1.09 & 0.37 & 0.63 & 0.56 \\
\hline Valerate & 1.09 & 1.05 & 1.39 & 0.20 & 0.59 & 0.24 \\
\hline Branched-chain FA & 1.85 & 1.76 & 1.87 & 0.24 & 0.91 & 0.75 \\
\hline Acetate:propionate & 2.78 & 2.49 & 2.57 & 0.28 & 0.46 & 0.84 \\
\hline \multicolumn{7}{|l|}{ Postpartum } \\
\hline $\mathrm{pH}$ & 6.91 & 6.89 & 6.61 & 0.13 & 0.31 & 0.12 \\
\hline $\mathrm{NH}_{3} \mathrm{~N}, \mathrm{mg} / \mathrm{dL}$ & 4.11 & 4.66 & 5.29 & 1.09 & 0.67 & 0.82 \\
\hline Total VFA, mM & 56.2 & 70.2 & 61.4 & 4.21 & 0.06 & 0.33 \\
\hline \multicolumn{7}{|l|}{ VFA, molar proportions } \\
\hline Acetate & 61.8 & 55.4 & 58.5 & 1.8 & 0.15 & 0.48 \\
\hline Propionate & 21.7 & 27.1 & 24.7 & 1.1 & 0.005 & 0.31 \\
\hline Isobutyrate & 1.07 & 0.86 & 0.89 & 0.11 & 0.20 & 0.74 \\
\hline Butyrate & 12.3 & 14.4 & 13.2 & 1.1 & 0.28 & 0.44 \\
\hline Isovalerate & 1.34 & 1.16 & 1.23 & 0.25 & 0.57 & 0.97 \\
\hline Valerate & 1.35 & 1.44 & 1.20 & 0.11 & 0.94 & 0.33 \\
\hline Branched-chain FA & 2.39 & 2.02 & 2.13 & 0.36 & 0.40 & 0.91 \\
\hline
\end{tabular}

${ }^{1} \mathrm{LG}=$ Glycerol at $430 \mathrm{~g} / \mathrm{d}, \mathrm{HG}=$ glycerol at $860 \mathrm{~g} / \mathrm{d}$.

${ }^{2}$ Contrasts: $1=\mathrm{C}$ vs. LG and HG, $2=\mathrm{LG}$ vs. HG.

erol flowing into the abomasum or absorbed across the rumen epithelium when drenched relative to the amount that is fermented when fed appears to determine the gluconeogenicity of glycerol in peripartum dairy cows. Bearing in mind the observed changes in ruminal fermentation patterns of cows fed glycerol and the fact that glycerol was undetectable in plasma, it is likely that the glycerol fed in the present study was predominantly used as an energy substrate by the rumen microorganisms instead of entering the gluconeogenic pathway as hypothesized.

Given the diet $\times$ day interaction of plasma glucose and BHBA concentrations (Figures $2 \mathrm{~A}$ and $3 \mathrm{~A}$ ) and the tendency for greater ruminal butyrate concentrations at 7 DIM, it is likely that the ruminal fermentation of glycerol may have further increased ruminal butyrate beyond the sample of rumen liquor collected at that day. This is especially true with regard to the inverse relationship between plasma glucose and BHBA in cows fed HG at $21 \mathrm{~d}$ postpartum. Undoubtedly, molar proportions and concentrations of butyrate (and other ruminal VFA) do not necessarily represent ruminal production rates (Dijkstra et al., 1993). An extensive ruminal sampling regimen was not used in the current study because the ruminal fermentation of glycerol was not a primary objective of the present experiment. However, countless other reports (Fisher et al., 1971; Rémond et al., 1993; Khalili et al., 1997; Schröder and Südekum, 1999) have found glycerol to increase concentrations of ruminal butyrate, downplaying the glucogenic ability of glycerol as described by others (Garton et al., 1961; Hobson and Mann, 1961; Czerkawski and Breckenridge, 1972). In addition, an intensive serial sampling protocol by Linke et al. (2004) found both feeding and drenching $800 \mathrm{~g}$ of glycerol to increase the molar percentage of ruminal butyrate and plasma BHBA. Because dietary shortchain fatty acids, mainly butyrate, are primary contributors to alimentary ketogenesis (Bergman, 1970), perhaps the ruminal fermentation of glycerol to butyrate increased plasma BHBA and decreased concentrations of glucose in plasma.

Body weight and body condition loss during the first 21 DIM was similar among treatments (Figure 1). This is paralleled by the similar concentrations of NEFA in plasma found among treatments (Figure 3B) as well as the similar liver lipid composition (Table 6). Feeding glycerol at levels used in this experiment did not have a significant impact on glucose and energy balance. Indeed, the predominant precursor giving rise to the postpartum increase in plasma BHBA in cows fed HG must have been derived from dietary short-chain fatty 
acids (butyrate) as opposed to free fatty acids released from adipose tissue.

\section{CONCLUSIONS}

Feeding glycerol-supplemented diets to transition dairy cows did not appear to exhibit the glucogenic effect attributed to it by researchers delivering glycerol via esophageal drench (Johnson, 1955; Goff and Horst, 2001). This conclusion is based upon a group of key indicators known to be critical to a successful transition cow program. The only effect of glycerol-supplemented diets prepartum was on DMI, which was decreased by $17 \%$, regardless of the amount of glycerol fed. In general, postpartum lactation performance was not affected by feeding glycerol; however, changes in ruminal profiles observed in cows fed glycerol included increased molar proportions of propionate, concentrations of butyrate, and a decreased ratio of acetate to propionate, all of which are in agreement with Linke et al. (2004). Feeding HG decreased postpartum concentrations of glucose and increased plasma BHBA from 7 to 21 DIM, a time when cows are most susceptible to ketosis (Gröhn and Erb, 1989). Although only reported as a tendency because of limited sample numbers, it is hypothesized that glycerol altered ruminal fermentation toward an increase in butyrate, as reported elsewhere (Fisher et al., 1971; Rémond et al., 1993; Khalili et al., 1997), prompting an increase in plasma BHBA. The data imply that glycerol should be delivered as a drench in hypoglycemic dairy cows and not fed as a component of transition dairy cow diets.

\section{ACKNOWLEDGMENTS}

Funding was provided by West Central Soy, Ralston, Iowa, and the South Dakota Agricultural Experiment Station. The authors express appreciation to personnel at the South Dakota State University Dairy Teaching and Research Farm for the feeding and care of the animals.

\section{REFERENCES}

Association of Official Analytical Chemists. 1990. Official Methods of Analysis. 15th ed. AOAC, Arlington, VA.

Association of Official Analytical Chemists. 1997. Official Methods of Analysis. 16th ed. AOAC Intl., Gaithersburg, MD.

Bergman, E. N. 1970. Symposium: Ketosis in dairy cows: Hyperketonemia-ketogenesis and ketone body metabolism. J. Dairy Sci. 54:936-948.

Bertics, S. J., R. R. Grummer, C. Cadorniga-Valino, and E. E. Stoddard. 1992. Effect of prepartum dry matter intake on liver triglyceride concentration in early lactation. J. Dairy Sci. 75:1914-1922.

Broderick, G. A., and J. H. Kang. 1980. Automated simultaneous determination of ammonia and total amino acids in ruminal fluid and in vitro media. J. Dairy Sci. 63:64-75.
Crandall, L. 2004. Glycerol abundance cause for concern. Inform 15:146-147.

Czerkawski, J. W., and G. Breckenridge. 1972. Fermentation of various glycolytic intermediates and other compounds by rumen micro-organisms, with particular reference to methane production. Br. J. Nutr. 27:131-146.

Derling, L. E., D. E. Brown, L. Castle, and L. Kelly. 1987. Muscle glycogen: Comparison of iodine binding and enzyme digestion assays and application to meat samples. Meat Sci. 20:167-177.

Dijkstra, J., H. Boer, J. Van Bruchem, M. Bruining, and S. Tamminga. 1993. Absorption of volatile fatty acids from the rumen of lactating dairy cows as influenced by volatile fatty acid concentration, $\mathrm{pH}$, and rumen liquid volume. Br. J. Nutr. 69:385-396.

Drackley, J. K., T. R. Overton, and G. N. Douglas. 2001. Adaptations of glucose and long-chain fatty acid metabolism in liver of dairy cows during the periparturient period. J. Dairy Sci. 84 (E Suppl.):E100-E112.

Fisher, L. J., J. D. Erfle, G. A. Lodge, and F. D. Sauer. 1973. Effects of propylene glycol or glycerol supplementation of the diet of dairy cows on feed intake, milk yield and composition, and incidence of ketosis. Can. J. Anim. Sci. 53:289-296.

Fisher, L. J., J. D. Erfle, and F. D. Sauer. 1971. Preliminary evaluation of the addition of glucogenic materials to the rations of lactating cows. Can. J. Anim. Sci. 51:721-727.

Garton, G. A., A. K. Lough, and E. Vioque. 1961. Glyceride hydrolysis and glycerol fermentation by sheep rumen contents. J. Gen. Microbiol. $25: 215-225$.

Goff, J. P., and R. L. Horst. 2001. Oral glycerol as an aid in the treatment of ketosis/fatty liver complex. J. Dairy Sci. 84(Suppl. 1):153. (Abstr.)

Gröhn, Y. T., and H. N. Erb. 1989. Epidemiology of metabolic disorders in dairy cattle: Associations among host characteristics, disease, and production. J. Dairy Sci. 72:1876-1885.

Hobson, P. N., and S. O. Mann. 1961. The isolation of glycerol-fermenting and lipolytic bacteria from the rumen of sheep. J. Gen. Microbiol. 25:227-240.

Johnson, M. J., and J. P. Peters. 1993. Technical note: An improved method to quantify nonesterified fatty acids in bovine plasma. J. Anim. Sci. 71:753-756.

Johnson, R. B. 1955. The treatment of ketosis with glycerol and propylene glycol. Cornell Vet. 44:6-21.

Khalili, H., T. Varvikko, V. Toivonen, K. Hissa, and M. Suvitie. 1997. The effects of added glycerol or unprotected free fatty acids or a combination of the two on silage intake, milk production, rumen fermentation and diet digestibility in cows given grass silage based diets. Ag. Food Sci. Finland. 6:349-362.

Leng, R. A. 1970. Glucose synthesis in ruminants. Pages 241-242 in Advances in Veterinary Science and Comparative Medicine. Vol. 14. C. A. Brandly and C. E. Cornelius, ed. Academic Press, New York, NY.

Lin, E. C. C. 1977. Glycerol utilization and its regulation in mammals. Annu. Rev. Biochem. 46:765-795.

Linke, P. L., J. M. DeFrain, A. R. Hippen, and P. W. Jardon. 2004. Ruminal and plasma responses in dairy cows to drenching or feeding glycerol. J. Dairy Sci. 87(Suppl. 1):343. (Abstr.)

Littell, R. C., G. A. Milliken, S. W. Walter, and R. D. Wolfinger. 1996. SAS Systems for Mixed Models. SAS Institute, Inc., Cary, NC.

Mills, S. E., D. C. Beitz, and J. W. Young. 1986. Characterization of metabolic changes during protocol for inducing lactation ketosis in dairy cows. J. Dairy Sci. 69:352-361.

National Research Council. 2001. Nutrient Requirements of Dairy Cattle. 7th rev. ed. Natl. Acad. Sci., Washington, DC.

Orth, R. 1992. Sample Day and Lactation Report. DHIA 200 Fact Sheet A-2. Mid-States DRPC, Ames, IA.

Rémond, B., E. Souday, and J. P. Jouany. 1993. In vitro and in vivo fermentation of glycerol by rumen microbes. Anim. Feed Sci. Technol. 41:121-132.

SAS User's Guide: Statistics, Version 8.01 Edition. 1999. SAS Inst., Inc., Cary, NC.

Schröder, A., and K.-H. Südekum. 1999. Glycerol as a by-product of biodiesel production in diets for ruminants. In New Horizons for an Old Crop. Proc. 10th Int. Rapeseed Congr., Canberra, Austra- 
lia, September 26-29, Paper No. 241. N. Wratten and P. A. Salisbury, ed.

Smith, T. R., A. R. Hippen, D. C. Beitz, and J. W. Young. 1997. Metabolic characteristics of induced ketosis in normal and obese dairy cows. J. Dairy Sci. 80:1569-1581.

Trinder, P. 1969. Determination of glucose in blood using glucose oxidase with an alternative oxygen acceptor. Ann. Clin. Biochem. 6:24-27.
Van Soest, P. J., J. B. Robertson, and B. A. Lewis. 1991. Methods for dietary fiber, neutral detergent fiber, and nonstarch polysaccharides in relation to animal nutrition. J. Dairy Sci. 74:35833597.

Wildman, E. E., G. M. Jones, P. E. Wagner, R. L. Bowman, H. F. Troutt, Jr., and T. N. Lesch. 1982. A dairy cow body condition scoring system and relationship to selected production characteristics. J. Dairy Sci. 65:495-501. 